TRADITIONAL AND NEW TYPES OF DIAMOND-BEARING ROCKS AND METHODS FOR THEIR ESTIMATION.

\title{
I.L. Komov.
}

Institute of Geochemistry and Physics of Minerals, Ukr. SSR Academy of Sciences, Kiev.

Diamond-bearing rocks comprise the following types: kimberlites, lamproites, impactites, eclogite-amphibolites and eclogite-gneiss metamorphic complexes, ultrabasic (uItrabasites) and basic (basaltoids) rocks.

Diamond in kimberlites is a polygenetic mineral and is genetically related to ultrabasic and basic mantle rocks. Kimberlitic magma transported diamond and other minerals of deep seated rocks (products of the mantle substratum disintegration). These conclusions are substantiated by radiological and mineralogical data, by crystal inclusions with octahedral cut (negative crystals) available in diamonds, whose deformation proceeded in the course of a long period of geological time (billion years and even more), by diamond presence in deep-rock senolyths of diverse composition. Peculiarities of the kimberlite composition are governed, as a rule, by the crystalline basement structure.

Natural geothermometers, the character of the dislocation structure of crystals, forms of nitrogen show that crystalization of diamonds occurred at a temperature of 1200-1500\% , the depth of formation being $200 \mathrm{~km}$ as much. These data necessitate important conclusions:

- the main techniques applied in search for diamond-bearing kimberlites are mineralogical and geophysical methods based on revealing structure-compositional and physical inbomogeneities of the kimberlite fields; the division of kimberlites into productive and perspectiveless cannot 
be realized by petrochemical and geochemical methods.

Urgent seems to be the problem of complex estimation of kimberlites and following extraction of gold, platinum and precious coloured stones - pyrope, chrysolite, chromediopside. The preservation of diamonds during rock processing can be done on the base of blending.

Large and rich diamond deposits abroad are associated with lamproites. Characteristic features of lamproites are their Mg, K, TI, $\mathrm{Zr}, \mathrm{Ba}$ enrichment by light rare-eartb elements, availability of olivine, phlogopite, richterite in rocks and presence of such potassium minerals as leucite, wadeite, jappeite, shcherbakovite as well as zircon, barite, garnet (of the pyrope series with low titanium contents), chrome-diopside, chromite. Geological mapping of lamproites and identification of proper olivine varieties among tufis are required for predictive work. The latter may be carried out in such a succession: geophysical research (magnetic prospecting, ondometric methods), geological mapping, geochemical work (detection of potassium, barium aureoles), drilling, mining sinking, large-scale bulk sampling with a view to produce a required quantity of diamonds, evaluation of their content and qualities. Large diameter wells are drilled with bulk sampling of the material (sample mass - 40kg).

In assessing the diamond content in metamorphous rocks the following characters are taken into account as their productivity criteria:

- wide varlations in the mineral and chemical composition of rocks, frequent alternation of very contrasting Precambrian geological formations metamorphosed under conditions of the amphibolitic facies of metamorphism; 
- the development of complex and variegated paragenesis of minerals in the zones of potassium metasomatism: graphite, quartz, feldspar, forsterite, biotite, phlogopite, muscovite, spinel, clinohumite, tourmalin, pyroxene (diopside, omphacite), garnet (pyrope-almandine, pyrope-grossular), dolomite, calcite. Diamonds contained in metamorphous formations are usually fine, green-yellow. Mineralogical (typomorphous signs of garnet, pyroxene) and geochemical features (by potassium aureoles) are used in search for diamonds. 